\title{
Fysikus Martin Reimers
}

\section{Af $F$. Reimers}

Planteriget, dyreriget og mineralriget dannede i gamle dage fundamentet for lægernes materia medica. Lægers videnskabelige nysgerrighed måtte derfor nødvendigvis føre til, at mange naturvidenskabelige opdagelser skyldtes læger. Nogle blev så grebet deraf, at de - som f.eks. Linné - nåede op $\mathrm{i}$ videnskabens højeste rangklasser. For andre var naturvidenskaben en med ildhu dyrket fritidsinteresse, som vel ikke gav de epokegørende resultater, men som dog på specielle områder kunne fremme kendskabet til planter, dyr eller - som i Martin Reimers tilfælde - forsteninger.

Han var landmandssøn fra det vestlige Holsten, Itzehoe-egnen, født 1812. Da han var ca. 13 år gammel overtog hans far forpagtningen af to gårde, senere yderligere 2, i Poppenbüttel lidt nord for Hamburg. ${ }^{1}$ Martin måtte her deltage i gårdenes drift; men det var boglig viden, han stræbte efter. Og det lykkedes ham, formodentlig med støtte af gårdenes ejer, pastor F. C. M. Führer, og en professor i Pinneberg, at komme i den lærde skole i Altona, hvorfra han, 21 år gammel, blev student i $1834 .^{2}$

Derefter studerede han medicin i Kiel, dog med studiet i et par år forlagt til København. En af hans lærere her var dronning Maries livlæge Joachim Dietrich Brandis, der tidligere havde været professor i Kiel, og som gæstfrit og hjælpsomt tog sig af sine holstenske studenter. Brandis nærede stor sympati for sin begavede elev, der ligesom han selv forenede en levende interesse for den klassiske litteratur med interessen for naturvidenskab. Martin Reimers havde derfor sin jævnlige gang i Brandis hjem - om sommeren i villaen Valhøj i Valby - hvad der ikke blot bidrog til hans uddannelse og åndelige berigelse, men også til, at han i 1842 blev gift med Brandis datter Marie.

Det medicinske studium afsluttedes med embedseksamen i Kiel i 1839 , hvorefter han i København udarbejdede en disputats om planternes respiration. ${ }^{3}$ Disputatsen indbragte ham i $1839 \mathrm{i}$ Kiel titlen doctor medicinae et chirurgiae. I 1843 tog han også fysikatseksamen i Kiel.

Allerede $i$ sin studietid havde han beskæftiget sig med et emne, der optog ham livet igennem: oldtidens botanik, hvori han kunne forene sin interesse for de klassiske forfattere og for botanik. Resultatet 
var en medicinalhistorisk afhandling om rabarberrod, offentliggjort i $1840 .^{4}$

Reimers nedsatte sig først som læge i Haderslev, hvor han desuden holdt en serie populærvidenskabelige foredrag med så forskelligartede emner som planternes farver, vulkaner, dyrenes instinkt m.m. Men i 1841 blev han af administratoren af Gram og Nybøl godser, amtmand G. H. E. v. Krogh, hentet som læge til Gram. ${ }^{5}$ Her fungerede han til sin død i 1876 som praktiserende læge, blev i 1853 fysikus for Haderslev vesteramt og i 1860 det nyoprettede sygehus' første læge. Hans eftermæle som læge går ud på, at han, med sit stilfærdige og bramfri væsen, der var præget af humanitet og velvilje, nød megen anerkendelse. Om hans virke $\mathrm{i}$ sygehuset kan læses i dettes 100 års jubilæumsskrift. ${ }^{6}$

Men ved siden af sin lægegerning dyrkede han med stor flid og indsigt sine mangesidede interesser som samler af planter og insekter, studier af den klassiske botanik og undersøgelser af de forsteninger, der fandtes i en nyoplukket lergrav i Gram.

Også inden for sit fag påtog han sig opgaver ud over de daglige pligter. I 1858 udgav han en Medicinal-Kalender for den danske Stat, ${ }^{7}$ der foruden kalender og forskelligartede oplysninger for læger indeholdt en afhandling af instrumentmager Nyrup om en fjedertryksmaskine, der bedre end de "torturlignende« stræksenge kunne rette skæve rygge.

Samme år offentliggjorde han $\mathrm{i}$ den danske avis Dannevirke en medicinalhistorisk beretning om blodgangen $\mathrm{i}$ Nordslesvig $\mathrm{i}$ årene 1658 og 1659. ${ }^{8}$ Hans største indsats på det lægelige område var dog udarbejdelse af en oversigt over lægemidler og en formelsamling, omfattende ca. 2000 receptformler, 'der $\mathrm{i}$ de sidste to Aarhundreder ere blevne anbefalede som særdeles virksomme«. Bogen repræsenterer et kolossalt og omhyggeligt samlearbejde. Han har her benyttet »de berømteste og paalideligste Lægers Erfaring, ligefra Sydenham til vor Bang ${ }^{9}{ }^{9}$ Men anmelderen i Ugeskrift for Læger var kritisk og mente, at i stedet for overensstemmelse med de enkelte forfatteres autentiske meddelelser burde der være overensstemmelse med videnskabernes daværende standpunkter! ${ }^{10}$

Som allerede nævnt havde han fra sin ungdom interesseret sig for oldtidens botanik, og efter $\mathrm{i}$ mange år at have indsamlet materiale, begyndte han i 1862 at nedskrive manuskriptet til "Oldtidens specielle Botanik med særligt Hensyn til Planternes Anvendelse og mythologiske Betydning. Efter Kilderne udarbeidet af Dr. M. Reimers «. ${ }^{11}$ Da udgivelsen af et sådant rent videnskabeligt værk næppe kunne ske på et 
Martin Reimers (1812-76) var lage i Gram fra 1841 og fysikus for $\mathrm{Ha}$ derslev Vesteramt fra 1853. Gramlerets berommelse blandt geologer skyldes bl.a. Reimers indsats. (Privateje).

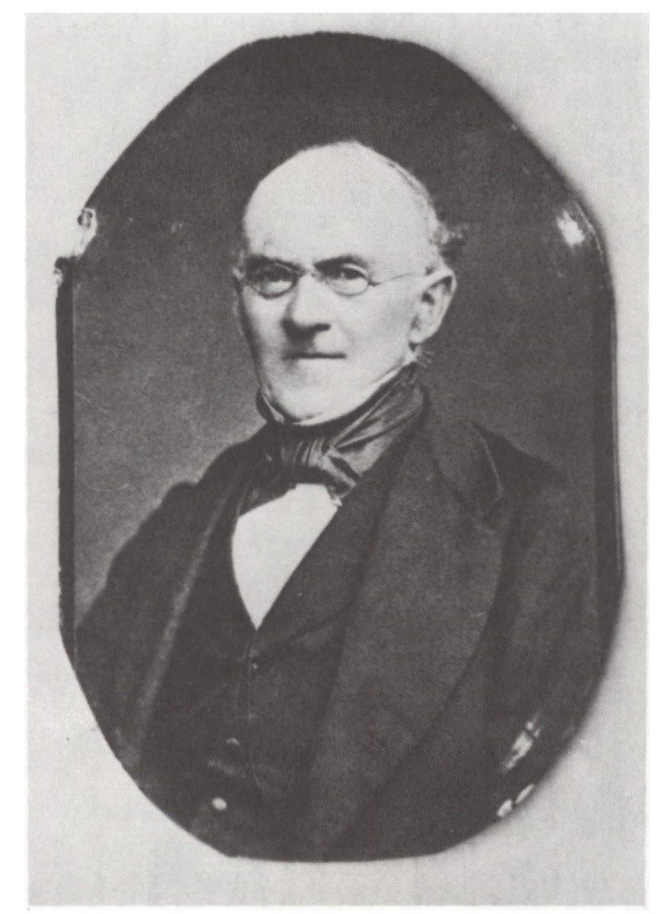

forlag, henvendte han sig gennem professor J. G. Forchhammer til Videnskabernes Selskab. ${ }^{12}$ Han forelagde selskabets første hæfte på 72 sider, omfattende 72 plantearter, men efter 2 års forløb afslog selskabet at udgive værket. Censorerne var naturforskeren professor Japetus Steenstrup og filologen og arkæologen J. L. Ussing. De stillede sig tvivlende over for rigtigheden af fortolkningen af de klassiske plantenavne, dog uden at påvise fejl, og kritiserede navnlig det rent formelle forhold, at de enkelte afsnit indledtes med plantens navn efter Linnés system, hvorved tydningen af det klassiske plantenavn var foregrebet. Et sådant værk burde snarere skrives af »en Filolog med botanisk Kendskab end af en Botaniker med filologisk Indsigt« omend "Dr. R. besidder mere heraf end de fleste ${ }^{13}{ }^{13}$

I ventetiden var yderligere 43 sider renskrevet; men arbejdet synes da brat afbrudt, efter at der af den sidste artikel kun var skrevet 2 linier. Efter hans død blev et afsnit offentliggjort, formentlig af hans søn, apoteker D. M. C. Reimers, i det danske apotekertidsskrift. ${ }^{14}$ Det har titlen: „Om Mandeltræet (Amygdalis communis L) i Oldtiden, en 
speciel Undersøgelse som den findes omtalt i den klassiske og orientalske Literatur, navnlig i den hebræiske, arabiske og syriske. Af afdøde Physikus M. Reimers i Gram«. Her er dog ikke medtaget noterne, hvori var gengivet henvisninger til og citater fra de klassiske forfattere.

I 1865 måtte Reimers i øvrigt konsultere professor Esmarch i Kiel for en øjensygdom. Han behandlede ham med en »kunstig igle«, mens han anbragtes i bælgmørke i 36 timer, og tilrådede ham kun at læse og skrive det allernødvendigste.

Hermed var hans muligheder for at fortsætte videnskabeligt arbejde meget små, og sygdommen har sikkert også været årsag til, at et andet botanisk storværk forblev uafsluttet, nemlig en »Phanerogamenflora«. Manuskriptet hertil foreligger $\mathrm{i}$ form af to bind med $\mathrm{i}$ alt ca. 500 sider med fine blyantstegninger af over 700 plantearter. Tegningerne er kopieret som udsnit af Flora Danica og andre værker, men er i modsætning til disse ordnet efter Linnés system. Var dette værk blevet afsluttet og udgivet, ville det have været en både meget smuk og nyttig billedflora. ${ }^{15}$

Martin Reimers opnåede således ikke at frembringe værker af blivende betydning inden for de områder af den klassiske filologi og naturvidenskaberne, som han helt fra sin ungdom havde beskæftiget sig med, vel nok bl.a. en følge af hans isolerede stilling som provinslæge, fjernt fra landets lærdomssæder. Men hans navn huskes dog stadig af dyrkerne af et andet naturvidenskabeligt speciale som følge af de undersøgelser, han foretog af fossiler $i$ ler, der blev fundet i nærheden af Gram Slotsby.

Hans undersøgelser medførte, at glimmerler, aflejret i tertiærtidens senere del, øvre miocæn, for ca. 15 millioner år siden $\mathrm{i}$ et hav, der strakte sig fra Midt- og Vestjylland ned over Nordtyskland og Holland, uanset hvor det findes, stadig betegnes Gram-ler og er karakteriseret ved en fossil musling, der har fået navnet Astarte Reimersi.

Hvordan Reimers kom ind på dette emne, kan man følge $\mathrm{i}$ den holstenske lærerforenings blad, der benyttedes som meddelelsesmiddel for en i 1855 oprettet Verein für Verbreitung naturwissenschaftlicher Kenntnisse. ${ }^{16}$ Foreningen opfordrede til samarbejde vedrørende landsdelens flora og fauna, mineraler, forsteninger m.m. Reimers har heri set en mulighed for udveksling af fund med ligesindede, indmeldte sig i foreningen og lod 7. juni 1856 meddele, at han kunne tilbyde sjældne planter og insekter fra Gram-egnen i udveksling. I samme nummer meddelte en amatørpalæontolog fra Altona, J. C. Semper, at han søgte 
at skaffe sig en så fuldstændig samling af navnlig tertiære forsteninger som muligt og kunne i bytte tilbyde udenlandske, navnlig italienske. Selv havde han samlet fossile snegle og muslinger fra Lüneburg, Holsten og fra Spandet i Slesvig, ikke langt fra Gram.

Netop på denne tid gjorde man i Gram den opdagelse, at der lidt nord for slotsbyen, i udkanten af skoven, fandtes usædvanlig fint ler kun lidt under overfladen. Efter at man havde konstateret, at lerlaget strakte sig langt til alle sider, besluttede grev Brockenhuus-Schack at oprette et teglværk. Dette kom snart i drift og leverede bl.a. stenene til det nye sygehus. ${ }^{17}$

Reimers, der var blevet opmærksom på, at ler kunne gemme interessante forekomster af forstenede bløddyrskaller, kunne allerede 14. januar 1857 meddele foreningen, at glimmerleret i Gram syntes at være endnu rigere på forsteninger end leret i Spandet.

Den 4. juli opfordrede Semper alle, der besad konkylier fra glimmerler, til at overlade ham dem til undersøgelse. Reimers må have fulgt opfordringen og bl.a. sendt ham en hidtil ukendt Astarte-art, der forekom i særlig stort antal i leret i Gram. Semper må have svaret, at han ved offentliggørelsen af sine undersøgelser ville beskrive arten og betegne den Astarte Reimersi Semper.

Sempers afhandling blev dog aldrig offentliggjort, men at den har eksisteret og været kendt af fagfolk fremgår bl.a. af en afhandling af A. v. Koenen ${ }^{18}$ og af, at da J. P. J. Ravn i 1907 gav den videnskabelige beskrivelse af arten, betegnede han den Astarte Reimersi Semper Ms. ${ }^{19}$

Martin Reimers har $\mathrm{i}$ forbindelse med sin korrespondance med professor Forchhammer om den klassiske botanik fortalt ham om sine fund i leret i Gram og i en lergrav i Storland, vest for Gram. Forchhammer var den, der først - i 1826 på øen Sild - havde konstateret tilstedeværelsen af tertiært glimmerler. På opfordring sendte Reimers ham med et brev, dateret 4. nov. 1862 (brevet har i engelsk oversættelse været publiceret af L. Banke Rasmussen), ${ }^{20} 33$ forskellige arter, herunder den omtalte Astarte i 12 eksemplarer. Han fortæller i brevet, at han yderligere har 29 arter i enkelte eksemplarer, og at han med de seneste fund, der ikke var endeligt bestemt, havde ca. 70 arter. ${ }^{21}$

Meddelelsen gav anledning til, at bl.a. Forchhammer og Semper aflagde Gram besøg, og at man mange andre steder konstaterede tilstedeværelse af Astarte Reimersi i glimmerler. Da malakologen $\mathrm{O}$. Mørck $^{22}$ i 1873 gennemgik samlingerne af tertiære fossiler i København, havde han således materiale fra bl.a. Reimers og Forchhammer til undersøgelse. Og da Ravn i 1907 gav sin beskrivelse af arten, havde 
han skaller i tusindvis fra 9 forskellige lokaliteter. Han fastslog, at arten måtte henføres til øvre miocæn. Arten er let genkendelig med den lige eller næsten lige midterste del af ventralranden og af de meget fine koncentriske ribber.

Først med Ravns beskrivelse var navnet officielt fastsat, og Banke Rasmussen betegnede derfor arten som Astarte Reimersi, Semper in Ravn 1907. ${ }^{23}$ Der har dog været rejst tvivl om berettigelsen af at betragte arten som selvstændig. ${ }^{24}$ Men i praksis har den bevaret navnet Astarte Reimersi og har, på grund af sin hyppighed og letgenkendelighed, fungeret som den ledefossil, der kendetegner Gram-leret. Dette har bl.a. haft betydning som hjælp til fastsættelse af de jyske brunkulslejers alder. $^{25}$

Astarte Reimersi var ikke den eneste art, der blev opkaldt efter Martin Reimers. Senere overlod han A. v. Koenen sine fund til undersøgelse, og denne skriver om en konkylie, der var fundet $i$ to eksemplarer, at de "gleichen keiner recenten oder fossilen Art auch nur annährend, und ich benenne sie nach dem Entdecker«. Den fik navnet Purpura Reimersi v. Koenen. Reimers egen samling blev i 1940 'rne overladt Naturhistorisk Musæum i Aarhus. ${ }^{26}$ Jeg har dog forgæves efterlyst den.

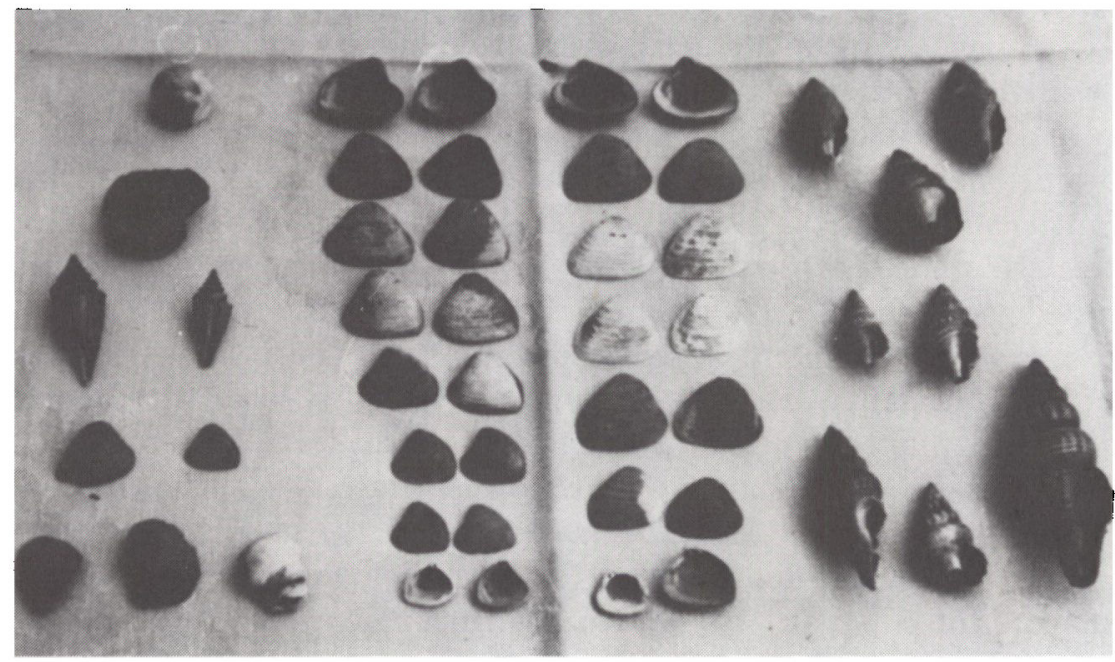

Gramleret er rigt pd fossiler. Den hyppigst forekommende muslingeart er Astarte Reimersi, opkaldt efter fysikus Martin Reimers. - Ovenstående er et eksempel på, hvad man $i$ vore dage kan finde $i$ lergraven på en formiddag. De 30 skaller $i$ midten er Astarte Reimersi. (Privateje) 
Gram har siden haft besøg af talrige, lærde og ulærde, der har søgt forsteninger i lergraven, der foruden fossile mollusker har vist sig at indeholde mange andre dyrerester fra hajtænder til hvaler, der kan beses i Midtsønderjyllands Museum i Gram Slot.

Det er ikke glemt, at det var Martin Reimers, der gav anledning til Gram-lerets berømmelse, hans navn nævnes, når dets fossiler omtales og dets historie og geologiske betydning berettes. ${ }^{27}$ I Gram har man glædet sig over, at byens navn er blevet knyttet til en internationalt anvendt betegnelse, og har opkaldt en villavej på Kirkebjerg, nær sygehuset og Martin Reimers' hjem, efter ham.

Den periode, i hvilken familien Reimers boede i Gram, hører til landsdelens mest bevægede med oprøret og krigen 1848-50, der endte med dansk sejr, og krigen 1864, der endte med hertugdømmernes afståelse. Gram-egnen var udpræget dansksindet. Efter 1848 måtte derfor den slesvig-holstenske administrator af Gram Slot fortrække, og den dansksindede godsinspektør J. M. Raunsøe overtog ledelsen. Man kunne have ventet, at holsteneren Martin Reimers og hans kone, datter af en tysk professor, kunne være mere tysk- end dansksindede. Af breve og beretninger fremgår imidlertid, at begge har været udpræget dansksindede. ${ }^{28}$ For at forstå, at også Martin Reimers kunne foretrække danskheden, må man erindre, at $\mathrm{i}$ hans barndom var der ikke $\mathrm{i}$ hans egn det modsætningsforhold mellem dansk og holstensk eller tysk, der opstod $\mathrm{i}$ det bevægede år 1830. Og under studieårene $\mathrm{i}$ København havde han i sin tilkommende kones hjem lejlighed til at træffe mange fremtrædende danske. ${ }^{29}$ Også preussernes optræden efter 1866 med arrestationer og udvisninger af dansksindede og indførelse af den pertentlige preussiske administration, der satte embedsmændene grå hår $i$ hovedet, kan have bidraget til at styrke hans venlige følelser over for danskheden. Og hertil kom, at familiens mange venner i Gram var udpræget dansksindede.

Martin Reimers blev som før omtalt på sine ældre dage plaget af øjensygdom, og da sygehusets patientantal, der i 1867 var steget til 471, i 1875 var faldet til 92, ønskede myndighederne undersøgt, hvad der kunne være årsag hertil. Herredsfogden svarede bl.a., at dr. Reimers var blevet meget nærsynet og ikke så sikker på hånden mere, men han kunne dog ikke med sikkerhed sige, at det var årsagen til tilbagegangen. Reimers kunne dog påvise, at nedgangen skyldtes, at der havde nedsat sig mange læger $\mathrm{i}$ omegnen, og at nedgangen ikke var større end for de øvrige mindre sygehuse. Og han fremhævede, at 
Gram sygehus havde den mindste dødelighed, nemlig kun 3\%, hvor den på de andre sygehuse lå mellem 6 og 12\%. Forfatteren til 100 års jubilæumsskriftet, $\mathrm{O}$. Christensen, afslutter beretningen herom: Vi må i dag give dr. Reimers ret. ${ }^{30}$

Martin Reimers, denne travle og pligtopfyldende mand, der, foruden at passe sin praksis, sine fysikatsforretninger og sygehuset, livet igennem tumlede med store og vanskelige opgaver, blev kun 63 år gammel. Den 4. februar 1876 døde han af en "Brystcathar, som gik over til Brystbetændelse«. Det var ikke gennem store offentliggjorte værker, hans navn blev bevaret for eftertiden. Men hans kærlighed til naturen parret med hans videnskabelige trang og flid har dog givet ham adgang til et lille hjørne af naturvidenskabernes historie.

\section{LITTERATURLISTE}

Beretningen bygger, foruden på den nedennæunte litteratur, på dokumenter og breve $\mathrm{i}$ forfatterens eje.

1. A. Clasen, W. Rehders \& G. Apel: Hummelbüttel und Poppenbüttel, Hamburg 1938.

2. Freja 23/2 1876 .

3. Martinus Reimers: Respirationis Plantarum Explicatio, Kiel 1839.

4. M. Reimers: C. W. Pfaffs pract. u. krit. Mitth. Med., Chir. u. Pharm., Neue Folge $16,39,1840$.

5. C. E. Andersen: Grams Historie, København 1926.

6. O. Christiansen: Haderslev Amts Sygehus i Gram 1860-1960, Haderslev 1960.

7. M. Reimers: Medicinal Kalender for den danske Stat for Aaret 1858, Haderslev.

8. M. Reimers: Dannevirke 21. Aarg. nr. 290 og 295, 1858.

9. M. Reimers: Oversigt over samtlige officinelle og nye Lagemidler med Angivelse af deres Former, Præparater og Doser samt en Samling særdeles virksomme og ved Erfaringen provede Receptformler med Anviisning til deres specielle Anvendelse. Til Brug for practiserende Læger, Kjøbenhavn 1860.

10. Anonym: Ugeskr. f. Læger 2. Rk., 32, 421, 1860.

11. Manuskript med mange forarbejder i Botanisk Centralbibliotek, København.

12. Koncept til henvendelsen findes $i$ det under 11 nævnte manuskript.

13. Betænkning i Det kgl. danske Videnskabernes Selskab, prot. nr. 8857/1863.

14. M. Reimers: Arch. Pharm. techn. Chemi 31, 120, 1877.

15. M. Reimers: Phanerogamenflora, bd. I-II, manuskript i forf. eje.

16. Schulzeitung für die Herzogthümer Schleswig, Holstein u. Lauenburg, 1856, s. 147 og 175,1857 , s. 82 og 184.

17. H. P. Sørensen: Træk af Gram Sogns historie, 1965.

18. A. v. Koenen: Schriften des Gesellsch. z. Beför. des gesammt. Naturwiss. zu Marburg, Bd. 10, Cassel 1872.

19. J. P. J. Ravn: Kgl. danske Vidensk. Selsk. Skrifter 7. Rk., naturvidensk. og math. afd. III, 2, 1907. 
20. L. Banke Rasmussen: Danm. geol. Unders. II Rk. nr. 88, 1966.

21. Brev i Geol. Musæums Bibl., København.

22. O. Mørch: 11. skand. Naturforskermøde i København 1873, 1874, 274.

23. L. Banke Rasmussen: Danm. geol. Unders. II Rk. nr. 81, 1956.

24. L. Banke Rasmussen: ibid. nr. 92, 1966.

25. B. E. Koch, M. L. Friederich, E. F. Kristensen \& E. M. Friis: Den miocæne brunkulsflora og dens geologiske miljø i Søby-Fasterholt området sydøst for Herning, Forskningsrapport nr. 1, Aarhus 1972.

26. M. Leth: Livlæge Joachim Dietrich Brandis, Aarhus 1944.

27. f. eks. L. Banke Rasmussen: Varv 1965, nr. 3, 23.

28. Caroline Emilie Andersen: Bidrag til Sønderjyllands Historie 1848-1867. Sønderjyske Årbøger 1927, f.eks. s. 34. Jvf. note 17.

29. Jvf. note 26.

30. Jvf. note 6 . 
